\title{
Study of College Students' Ideological Education Carriers Based on
}

\section{Network Background}

\author{
Li Jun ${ }^{1, a^{*}}$ \\ ${ }^{1}$ Shaanxi University of Chinese medicine, Xianyang, Shaanxi 712046, China \\ aemail: baojilijunjun@163.com
}

Keywords: Network background; college students' ideological education; carrier

\begin{abstract}
The rapid development of network technology has a major impact on College Students' Ideological and poses a challenge on authoritative of ideological education. Therefore, how to effectively use the new network carrier to optimize the development of college students' ideological education has become an important issue of concern educators based on Network Background. This paper also studied for this problem. Explore how to achieve ideological and educational support in the effective application of the network background, to continuously improve the ideological education level of college students. Firstly, the ideological education of college students to analyze the content. Then outlined the carrier and change direction ideological education. Then this paper Ideological Education Carrier practice function study and propose implementation strategies. I wish to conduct research on college students' ideological education background through network carrier under this article, then to provide reference for college students' education.
\end{abstract}

\section{Introduction}

With the intelligent mobile terminal technology continued to mature and popularity of a variety of interactive information carrier emerged, it seems to have entered into the Internet age. In this case, college students use microblogging, micro-channel, micro-public information and other new communication tools to obtain information. To some extent, This information will affect the ideological, and give ideological education of college students to bring some opportunities and challenges. Therefore, it should be rational use these new carriers to optimize the implementation of ideological education, to promote education of college students in line with the characteristics of the Internet age, and can be effectively implemented, and can be a good education and training students, prompt students to establish the correct values, outlook on life, world outlook and create conditions for future college students can better development. Therefore, this paper explored to effectively use the new network carrier to optimize the development of college students' ideological education. Firstly, the ideological education of college students to analyze the content. Then outlined the carrier and change direction Ideological Education. Then this paper Ideological Education Carrier practice function study and propose implementation strategies.I wish to conduct research on college students' ideological education background through network carrier under this article, then to provide reference for college students education.

\section{College students' ideological education content and carrier based on network technology}

Analysis of college students' ideological education content. Universities from the build process of the overall education system, the college education of our focus on developing students' 
comprehensive ability and social ability. In essence, we grew up in our social environment in the New Period generation of students, their development showing a more obvious personalized trends. Under such circumstances, the higher education system of ideological education classroom teaching, the teaching objectives of the course is different from other basic disciplines. Teachers do need professional education of college students in the task of teaching both at the same time, and grasp the students ideological trends, thus helping students to establish a correct outlook on life and values.

College students' ideological education carrier. From a theoretical study to analyze, the ideological education of college students is a more special professional education courses. It is different with the knowledge, skills, types of courses. In his own ideological education and guidance is based. Therefore, we need to complete carrier with education teaching task. Course System for Higher Education among the ideological education, education carrier choice is particularly important. Ideological Education Carrier refers to the process embodiment of ideological education of college students in universities, carry a certain amount of ideological education information, and in its action, efficient and accurate delivery to the student population used to promote the occurrence of mutual education subject and object the role of a form of activity and physical entities.

Change direction of ideological education carriers. In the current atmosphere of the Internet age, the main content of Ideological Education passed on to the student body, is not an easy task. The use of educational methods to determine the choice of the vector is the practice of education and educational objectives of problems in the process. On the current ideological education environment, ideological and educational support to be able to take into account to determine the three aspects, first, as a carrier of ideological and education, to be able to carry the core of ideological education and educational objective information; Second the contact carrier can play a role in education to build a bridge between subject and object of education; thirdly, the carrier has certain operational and able to play a certain effect of ideological education, the effective completion of university Thought teaching tasks, while college students to accept their excellent degree.

\section{Practice and enforcement strategy of college students' ideological education carrier based on network technology}

Practice study of college students' ideological education carrier based on network technology. Carrier Ideological education is an objective existence, using appropriate carrier to implement education can effectively promote the absorption of Students' educational content, and to ensure smooth conduct of the Ideological Education to a certain extent.Can be clearly seen from the educational practice at this stage, the web-based media tools ideological education effectiveness has improved than in the past, this ideological and political education and the choice of new "carrier" of the capabilities closely contact. Overall, the carrier Ideological Education with three main functions, includes carrying function, conduction and educational function.

Certain carrying capabilities

In the past, some students think that the main ideological content of teaching subjects rather dull. In essence, the main problem due to the use of educational models and teaching methods appear. Late, the vast majority of universities have adopted the mobile network terminal vehicle and other ways to promote ideological education of college students, and achieved certain learning outcomes. This function depends on carrying Ideological education support, and with the help of this functional role under the ideological content of education and attach on "carrier", so as to deliver ideological content of education, and other elements of information to target groups of students, and the 
formation of benign interaction atmosphere.

Certain conduction function

In addition to college students' ideological education support "bearer" functionality, this "carrier" functional role in the actual teaching process more prominent is its conduction. In simple terms, "carrier" of conduction is to feature its ideological content of education itself can carry, goals take some form of transfer, to be presented to the student population, and be able to get some feedback, so that students understand this whether the content of education to understand and absorb. Should necessary, the need to stimulate "vector" which conduction feedback modules to a deeper grasp of students' personal behavior and ethical conduct and other aspects of the data.

Certain educational function

Ideological Education "carrier" with the educational function of the nature of its functions, in essence, the "carrier" carrier conduction function and is laying the groundwork for its educational function, that is, as the proper ideological education of college students "carrier", the first college students to be able to attract attention, and carry some educational content, while also able to pass out of the body content, then, can the student feedback on the educational content back to the education platform, in order to achieve the ultimate purpose of ideological education. Exert ideological and educational function of the carrier as the leading colleges and universities reflect the characteristics of the subject of education, it will be passed to the content of ideological and political ideas of the student population, and other ethical systems to effectively stand out, which played a certain role in education.

Executive strategy study of college students' ideological education based on network technology. In the new era environment, people's ideas have changed. Various construction and development of industrial society needs strong ideological and political foundation and have some practical ability of high-quality personnel. Affected Internet platform development, all sectors of society have undergone great changes. In the complex environment of new media of information transmission network, the network and media development for the majority of young people in terms of very close. But given the complexity of the network led to the presence of young people in the information when subjected to impact, is often difficult to identify the correct course. Thus, in the system of university education, the need to further implement the ideological and educational work, and that the use of network tools themselves to carry out ideological education of college students, the effect is more prominent.

College education must face up to the impact of college students on the network environment. In today's college campuses, "90" students have become the main campus. This generation of students is a new generation growing up in times of peace, and strongly influenced by the market economy. At the same time, this generation of young people has been deeply rooted influence of online media, the vast majority of cities and towns almost all college students have grown up in a network environment. Because of this, the practice of ideological education in colleges and universities, you need to change the past, the idea of education, and to stand as much as possible to consider the perspective of college students' ideological education, and gradually guide the contemporary college students understand the traditional ideological stance, encourage better enhance its the level of their ability to meet the requirements of the new era of social and economic environment in institutional development.

Actively build the campus network platform then penetrate ideological education content into it. Ideological education for a new generation of young people in terms of the more significant, it would help them establish a correct outlook on life and values the role. Based on this, the university needs to actively build the campus network platform, and the contents of ideological education into 
one, so easy to accept the ideological education of students, student groups to avoid this educational content repulsion.

Adjustment of ideological education and the strengthening of efforts to university network platform construction.Currently, over complex and diverse Internet platform, college students can come into contact with the huge amount of information. This is true, just ideological education has become particularly important. At the same time, the choice of the Ideological education model is also very crucial. With "Campus Network", "campus micro-channel public number", "campus microblogging service terminal" education "carrier", it is possible to further improve the quality and effectiveness of ideological and political education.

In short, the ideological education of the college classroom in terms of the effect on education is not ideal. Based on this, in the development of network information platform in full swing in the background, we need to use the Internet and mobile Internet platform to promote the education of college students. Ideological Education in Colleges and Universities to face a positive impact on the contemporary college students network environment brings, he changed the vision of college students, college students expand their knowledge, which for its future development is extremely beneficial. Therefore, schools should be taken against the current actual situation of flexible teaching strategies to educate college students as the main teaching and learning needs of its guide, the phased reinforce ideological education of college students, so as to enhance the effectiveness of ideological education of college students.

\section{Conclusions}

In the background of the network, development and application of new carrier about microblogging, micro-channel, micro-video, and other micro-public, brings a great impact on education of college students.In this case, the ideological educators should be rational use of these new carriers to promote knowledge and professors thought to improve ideological education level of college students.By analyzing network under the background of college students' ideological education "carrier" substance and binding "carriers" functional role in the education process itself Ideological as to reflect the country can be more intuitive to learn this type of curriculum. "carriers" Choose is important to higher education under network environment brought about the Enlightenment.To analyze the effects from educational practice, college Management in the implementation of ideological education faces the impact of network environment on college students brought, and actively build the campus network platform, then uses the "Campus Network", "campus micro-channel public number", etc.

\section{References}

[1]Lin Y B. To Strengthen College Students' Ideological Education with Employment Guidance as the Carrier[J]. Journal of Jilin Institute of Chemical Technology, 2014.

[2]Ying L I. On the Network Carrier of College Ideological Education[J]. Journal of Changchun Finance College, 2012.

[3]Zhanxia W. The Carrier Study of College Students' Ideological and Political Education in 4G Context[J]. Atlantis Press, 2014.

[4]Zhang J, Xiumei H E. College Students' Ideological and Political Education Carrier Analysis Based on Collaborative Innovation[J]. Guide of Science \& Education, 2014. 